\title{
DETERMINAN MANAJEMEN LABA AKRUAL PADA INDEKS LQ45 DAN JII PERIODE 2010-2015
}

\author{
Rina Trisnawati ${ }^{1)}$ Mardayaningrum $^{2)}$ Laillatul Khotimah $^{3)}$ \\ ${ }^{1}$ Fakultas Ekonomi dan Bisnis, Universitas Muhammadiyah Surakarta \\ rina.trisnawati@ums.ac.id \\ ${ }^{2}$ Fakultas Ekonomi dan Bisnis, Universitas Muhammadiyah Surakarta \\ mardairum@gmail.com \\ ${ }^{3}$ Fakultas Ekonomi dan Bisnis, Universitas Muhammadiyah Surakarta \\ laillatulkhotimah34@gmail.com
}

\begin{abstract}
The purpose of this study is to examine and analyze the mechanisms of corporate governance, leverage and the free cash flow against the accrual earning management on LQ45 and JII Indexes during the 2010-2015 period. The number of samples in the study is 144 companies in JII index and 121 companies in JII indexs. Sampling techniques using purposive sampling method. Methods of data analysis using multiple linear regression to test and prove the hypothesis of the study. Research results showed the proxy of corporate governance mechanism with institutional ownership, managerial ownership, the proportion of Board of Commissioners and the audit committee no effect to accrual earnings management.(prob value >0.05). The free cash flow and leverage have an effect significantly to accrual earning management (prob value <0.05). Meanwhile in JII index, they have the same results. Corporate governance also no effect to accrual earning management, but the free cash flow and leverage have an effect significantly to accrual earning management.
\end{abstract}

Keywords: corporate governance, leverage, free cash flow, accrual earnings management

\section{PENDAHULUAN}

Laporan keuangan merupakan sumber informasi penting tentang kondisi dan kinerja perusahaan bagi pihak ekternal dalam pengambilan keputusan. Adapun informasi yang diberikan mengenai posisi keuangan, kinerja, dan perubahan posisi keuangan suatu perusahaan. Laba merupakan informasi penting dalam laporan keuangan yang digunakan sebagai dasar pengambilan keputusan investasi. Selain itu, laba juga digunakan untuk mengukur kinerja manajemen. Oleh karena itu, manajer berusaha membuat laporan keuangan agar terlihat baik, cara yang biasa dilakukan adalah manajemen laba.

Manajemen laba timbul sebagai dampak persoalan keagenan yaitu ketidakselarasan kepentingan antara manajer dan pemilik perusahaan yang dikarenakan adanya asimetri informasi (Christiani dan Nugrahanti, 2014). Adanya asimetri informasi dan kecenderungan dari pihak eksternal (investor) untuk lebih memperhatikan informasi laba sebagai parameter kinerja perusahaan, akan mendorong manajemen untuk melakukan manipulasi dalam menunjukkan informasi laba, yang disebut sebagai manajemen laba (earnings management). (Agustia, 2013)
Upaya yang dilakukan oleh perusahaan untuk mengatasi manajemen laba adalah dengan menerapkan mekanisme corporate governance. Mekanisme corporate governance ditandai dengan adanya kepemilikan institusional, kepemilikan manajerial, dewan komisaris, dan komite audit. Struktur dari corporate governance juga menjelaskan bagaimana aturan dan prosedur dalam pengambilan dan pemutusan kebijakan sehingga dengan melakukan itu semua maka tujuan persahaan dan pemantauan kinerjanya dapat dipertanggung jawabkan dan dilakukan dengan baik (Sari dan Astika, 2015).

Rasio leverage menggambarkan sumber dana operasi yang digunakan oleh perusahaan. Rasio leverage juga menunjukkan risiko yang dihadapi oleh perusahaan. Semakin besar risiko yang dihadapi oleh perusahaan maka ketidakpastian untuk menghasilkan laba dimasa depan juga akan semakin meningkat. Hutang juga dapat digunakan untuk memprediksi keuntungan yang kemungkinan bisa diperoleh bagi investor jika berinvestasi pada suatu perusahaan (Agustia, 2013). Leverage yang tinggi akan meningkatkan perilaku oportunitis manajemen seperti melakukan manajemen laba, untuk mempertahankan kinerjanya dimata pemegang saham dan publik dan hal 
ini merupakan akibat dari kurangnya pengawasan (Sari dan Astika, 2015).

Salah satu faktor yang mempengaruhi praktik manajemen laba dan pentingnya penerapan corporate governance serta mengetahui peranan auditor dalam meminimalisir dan mendeteksi manajemen laba adalah free cash flow. Perusahaan dengan arus kas bebas (free cash flow) yang tinggi akan memiliki kesempatan yang lebih besar untuk melakukan manajemen laba, karena perusahaan tersebut terindikasi menghadapi masalah keagenan yang lebih besar (Agustia, 2013).

Penelitian ini bertujuan untuk menganalisis pengaruh corporate governance yang diproksikan dengan kepemilikan institusional, kepemilikan manajerial, proporsi dewan komisaris independen dan komite audit, dan leverage serta free cash flow terhadap manajemen laba akrual pada perusahaan yang terdaftar di Indeks LQ 45 dan JII Bursa Efek Indonesia periode 2010-2015

\section{KAJIAN LITERATUR DAN PENGEMBANGAN HIPOTESIS}

Teori Keagenan

Teori yang digunakan untuk memahami mekanisme corporate governance adalah teori keagenan. Jansen dan Meckling (1976) menyatakan bahwa hubungan keagenan adalah sebuah kontrak antara manajer (agen) dengan investor (principal). Munculnya konflik keagenan dipicu dengan adanya biaya keagenan karena kemungkinan agen bertindak tidak sesuai dengan kepentingan principal.

Elisenthart (1989) menyatakan bahwa tiga asumsi sifat dasar manusia yang digunakan untuk menjelaskan teori agensi adalah (1) manusia pada umumnya mementingkan diri sendiri (self interest) (2) manusia memiliki daya pikir terbatas mengenai persepsi yang akan datang (bounded rationality) (3) manusia selalu menghindari risiko (risk averse). Berdasarkan asumsi sifat dasar manusia tersebut manager sebagai manusia akan bertindak opportunistic, yaitu mengutamakan kepentingan pribadinya.

\section{Manajemen Laba}

Fisher dan Rosenzweigh (1995) dalam Kusumaningtyas (2012) mendefinisikan manajemen laba sebagai tindakan seorang manajer dengan menyajikan laporan yang menaikkan atau menurunkan laba periode berjalan dari unit usaha yang menjadi tanggung jawabnya, tanpa menimbulkan kenaikan atau penurunan profitabilitas ekonomi unit tersebut dalam jangka panjang. Manajemen laba akrual merupakan teknik yang biasa digunakan dalam pengelolaan laba. Menurut Healy (1985) dalam Christiani dan Nugrahanti (2014) konsep model akrual memiliki dua komponen, yaitu discretionary accruals dan non discretionary accruals. Discretionary accruals merupakan komponen akrual yang dapat diatur dan direkayasa sesuai dengan kebijakan (discretion) manajerial, sementara non discretionary accruals merupakan komponen akrual yang tidak dapat diatur dan direkayasa sesuai dengan kebijakan manajer perusahaan. Manajer akan melakukan manajemen laba dengan manipulasi akrual-akrual tersebut untuk mencapai tingkat pendapatan yang diinginkan.

\section{Corporate Governance}

Menurut Agustia (2013), corporate governance merupakan suatu sistem yang mengarahkan dan mengendalikan perusahaan dengan tujuan agar mencapai kesinambungan antara kekuatan kewenangan yang diperlukan oleh perusahaan untuk menjamin kelangsungan eksistensinya dan pertanggung-jawaban kepada stakeholder.

Manfaat corporate governance menurut Forum of Corporate Governance in Indonesia (FCGI, 2001) adalah : (1) Meningkatkan kinerja perusahaan melalui terciptanya proses pengambilan keputusan yang lebih baik, meningkatkan efisiensi operasional perusahaan serta lebih meningkatkan pelayanan terhadap stakeholders. (2) Mempermudah diperolehnya dana pembiayaan yang lebih murah sehingga dapat meningkatkan corporate value. (3) Mengembalikan kepercayaan investor untuk menanamkan modalnya di Indonesia. (4) Pemegang saham akan merasa puas dengan kinerja perusahaan karena sekaligus akan meningkatkan shareholder value dan dividen.

Prinsip-prinsip dasar dalam penerapan corporate governance yang dikemukakan oleh Forum of Corporate Governance in Indonesia (FCGI, 2001) adalah: (1) Fairness (keadilan). Menjamin adanya perlakuan adil dan setara di dalam memenuhi hak-hak stakeholders yang timbul berdasarkan perjanjian serta peraturan perundang-undangan yang berlaku. Prinsip ini menekankan bahwa semua pihak, yaitu baik pemegang saham minoritas maupun asing harus diberlakukan sama. (2) Transparency (transparansi). 
Mewajibkan adanya suatu informasi terbuka, akurat, dan tepat pada waktunya mengenai semua hal yang penting bagi kinerja perusahaan, kepemilikan, dan para pemegang kepentingan (stakeholders). Accountability (akuntabilitas). Menjelaskan fungsi, struktur, sistem, dan pertanggungjawaban perusahaan sehingga pengelolaan perusahaan terlaksana secara efektif. Prinsip ini menegaskan pertanggungjawaban manajemen terhadap perusahaan dan para pemengang saham. (4) Responsibility (pertanggungjawaban). Memastikan kesesuaian (kepatuhan) di dalam pengelolaan perusahaan terhadap korporasi yang sehat serta peraturan perundangan yang berlaku. Dalam hal ini perusahaan memiliki tanggungjawab sosial terhadap masyarakat atau stakeholders dan menghindari penyalahgunaan kekuasaan dan menjunjung etika bisnis serta tetap menjaga lingkungan bisnis yang sehat.

\section{Pengembangan Hipotesis}

\section{Kepemilikan Institusional dan Manajemen Laba Akrual}

Kepemilikan institusional memiliki kemampuan untuk mengendalikan pihak manajemen malalui proses monitoring secara efektif sehingga dapat mengurangi manajemen laba. Kusumaningtyas (2012) menyatakan prosentase saham tertentu yang dimiliki oleh institusi dapat mempengaruhi proses penyusunan laporan keuangan yang tidak menutup kemungkinan terdapat akrualisasi sesuaian kepentingan pihak manajemen.Siregar dan Utama (2005) menemukan adanya hubungan negatif antara discretionary accrual yang tidak diekspektasi dengan imbal hasil saham disekitar tanggal pengumuman. Dimana hubungan negatif tersebut bervariasi tergantung tingkat kecanggihan investor, dimana reaksi pasar dari investor yang lebih canggih mendahului investor yang tidak canggih. Sedangkan hasil penelitian dari Guna dan Herawati (2010) menyatakan bahwa kepemilikan institusional tidak berpengaruh terhadap manajemen laba. Berdasarkan uraian tersebut, maka hipotesis yang diajukan sebagai berikut:

$\mathrm{H}_{1}$ : Kepemilikan institusional berpengaruh terhadap manajemen laba Akrual

\section{Kepemilikan Manajerial dan Manajemen Laba Akrual}

Perusahaan meningkatkan kepemilikan manajerial untuk mensejajarkan kedudukan manajer dengan pemegang saham sehingga bertindak sesuai dengan keinginan pemegang saham. Dengan meningkatnya persentase kepemilikan, manajer termotifasi untuk meningkatkan kinerja dan bertanggungjawab meningkatkan kemakmuran pemegang saham. Kepemilikan seorang manajer akan ikut menentukan kebijakan dan pengambilan keputusan terhadap metode akuntansi yang diterapkan pada perusahaan yang mereka kelola. Persentase tertentu kepemilikan saham oleh pihak manajemen cenderung mengurangi tindakan manajemen laba (Zeptian 2013). Hasil penelitian Wahidawati (2002) serta Oktovianti dan Agustia (2012) menyatakan bahwa kepemilikan manajerial berpengaruh negatif signifikan terhadap manajemen laba. Sedangkan hasil penelitian Guna dan Herawati (2010) menyatakan kepemilikan manajerial tidak berpengaruh terhadap manajemen laba. Berdasarkan uraian tersebut, maka hipotesis yang diajukan sebagai berikut:

\section{$\mathrm{H}_{2}$ : Kepemilikan manajerial berpengaruh terhadap manajemen laba akrual}

\section{Proporsi Dewan Komisaris Independen dan Manajemen Laba}

Komposisi dewan komisaris merupakan salah satu karakteristik dewan yang berhubungan dengan kandungan informasi laba. Melalui perannya dalam menjalankan fungsi pengawasan, komposisi dewan komisaris dapat mempengaruhi pihak manajemen dalam menyusun laporan keuangan sehingga dapat diperoleh suatu laporan laba yang berkualitas (Farida, 2012). Hasil penelian Kouki et al (2011) yang melakukan penelitian dengan mengambil sampel dari setiap sektor industri menghasilkan kesimpulan bahwa komisaris independen berpengaruh negatif terhadap praktik manajemen laba, kesimpulan ini diperkuat dengan penelitian Dewanto (2012) yang juga memperoleh hasil bahwa proporsi dewan komisaris terbukti berpengaruh negatif terhadap praktik manajemen laba. Sedangkan hasil dari penelitian yang dilakukan oleh Oktovianti dan Agustia (2012) menyimpulkan bahwa proporsi dewan komisaris tidak berpengaruh terhadap manajemen laba. Berdasarkan uraian tersebut, maka hipotesis yang diajukan sebagai berikut: 


\section{$\mathrm{H}_{3}$ : Proporsi dewan komisaris berpengaruh terhadap manajemen laba akrual}

\section{Komite Audit dan Manajemen Laba Akrual}

Faktor utama dari sebagian besar penelitian komite audit adalah independensi anggota komite audit. Laporan keuangan yang dihasilkan oleh anggota audit yang independen akan lebih berkualitas. Karena semakin independen anggota audit, maka kualitas laporan keungan perusahaan akan lebih dipercaya. Hasil penelitian oleh Lin et al (2006) dan Alves (2011) mengungkapkan kesimpulan yang sama, yaitu keberadaan komite audit di perusahaan terbukti berpengaruh negatif terhadap praktik manajemen laba. Sedangkan hasil dari penelitian Zeptian dan Rohman (2013) membuktikan bahwa komite audit tidak berpengaruh terhadap manajemen laba. Berdasarkan uraian tersebut, dalam penelitian ini diajukan sebagai berikut :

\section{$\mathrm{H}_{4}$ : keberadaan komite audit berpengaruh terhadap manajemen laba akrual}

\section{Leverage dan Manajemen Laba Akrual}

Pambudi dan Sumantri (2014) mengatakan

Leverage dapat menjadi tolak ukur mengenai manajemen laba yang dilakukan oleh perusahaan. Perusahaan dengan leverage yang tinggi berarti memiliki liabilitas yang lebih besar jika dibandingkan dengan aset yang dimiliki, hal ini mengakibatkan risiko dan tekanan yang besar dalam perusahaan. Dalam kondisi perusahaan dengan leverage tinggi, manajer melakukan manajemen laba agar dapat menarik kreditor dan menunjukkan kepada pasar bahwa kinerja perusahaan baik, walaupun sebenarnya perusahaan tersebut memiliki risiko yang besar karena hutangnya (Elfira, 2014). Penelitian Shanti dan Yudharti (2007), serta Purwanti (2012) menemukan bahwa perusahaan yang memiliki financial laverage tinggi akibat besarnya liabilitas dibandingkan dengan aktiva yang dimiliki perusahaan, diduga melakukan manajemen laba karena perusahaan terancam default, yaitu tidak dapat memenuhi kewajiban membayar liabilitas pada waktunya. Penelitian yang dilakukan oleh Sari dan Astika (2015) berhasil membuktikan bahwa leverage berpengaruh terhadap manajemen laba. Berdasarkan uraian tersebut, maka hipotesis yang diajukan sebagai berikut:

\section{$\mathrm{H}_{5}$ : Leverage berpengaruh terhadap manajemen laba akrual}

\section{Free Cash Flow dan Manajemen Laba}

Free cash flow yang besar dalam perusahaan cenderung akan mempunyai level hutang yang tinggi untuk meminimumkan biaya keagenan dari free cash flow (agency cost of free cash flow). Free cash flow yang tinggi memaksa manajemen untuk mendistribusikan kepada pemegang saham dalam bentuk deviden. Pembayaran deviden yang lebih tinggi inilah yang memaksa manajemen perusahaan untuk mencari tambahan dana ke pihak luar dalam bentuk hutang agar manajemen tetap dapat merealisasikan rencana investasinya, melunasi hutang, membeli saham treasury, dan menambah likuiditas karena dana internal tidak mencukupi (Wahidawati, 2014). Hasil penelitian Isnawati (2011) menyatakan bahwa free cash flow berpengaruh negatif signifikan terhadap manajemen laba. Hasil penelitian yang dilakukan oleh Yoghi dan Damatanthi (2016) membuktikan bahwa free cash flow berpengaruh terhadap manajemen laba. Berdasarkan uraian tersebut, maka hipotesis yang diajukan sebagai berikut:

$\mathrm{H}_{6}$ : Free cash flow berpengaruh terhadap manajemen laba

\section{METODE PENELITIAN}

Populasi dalam penelitian ini adalah perusahaan yang terdaftar di dalam Bursa Efek Indonesia (BEI) pada index LQ45 dan JII periode 2010-2015. Teknik pengambilan sampel menggunakan metode purposive sampling Teknis analisis data yang digunakan adalah regresi berganda. Data yang digunakan data sekunder. yang bersumber dari www.idx.co.id dan Indonesian Capital Market Directory (ICMD) serta laporan keuangan yang telah diaudit. Proses pengambilan sampel dapat dijelaskan pada tabel 1 berikut ini.

Tabel 1

Pengambilan sampel

\begin{tabular}{clcc}
\hline \hline No & \multicolumn{1}{c}{ Keterangan } & LQ45 & JII \\
\hline & $\begin{array}{l}\text { Populasi perusahaan (6 } \\
\text { tahun) } \\
\text { Periode laporan keuangan } \\
\text { yang dilaporkan tidak } \\
\text { berakhir pada 31 Desember. }\end{array}$ & (28) & (10) \\
\hline \hline
\end{tabular}




\begin{tabular}{clll}
\hline \hline 2 & $\begin{array}{l}\text { perusahaan tidak menerbitkan } \\
\text { annual report secara lengkap. } \\
\text { Perusahaan non manukatur } \\
\text { (perbankan, asuransi, dan } \\
\text { keuangan lainnya). } \\
\text { Perusahaan yang tidak } \\
\text { melaporkan laporan } \\
\text { keuangan dengan satuan } \\
\text { rupiah. } \\
\text { Outlier }\end{array}$ \\
$\quad$ Sampel akhir & $(29)$ \\
& & \\
& $\mathbf{1 4 4}$
\end{tabular}

sumber : Data sekunder diolah

\section{Pengukuran Variabel Dan Definisi Operasional}

\section{a. Manajemen Laba}

Variabel dependen adalah manajemen laba, yaitu tindakan manajemen utuk meningkatkan (mengurangi) laba yang dilaporkan saat ini atas suatu unit dimana manajer bertanggungjawab tanpa mengakibatkan peningkatan (penurunan) profitabilitas ekonomis jangka panjang unit tersebut. Diproksi dengan discretionary accrual dan dihitung dengan modified jones model.

\section{Langkah I}

Menghitung total accruals perusahaan i pada periode $\mathrm{t}$ menggunakan rumus:

$\mathrm{TACC}_{\mathrm{it}}=\mathrm{EBXT}_{\mathrm{it}}-\mathrm{OCF}_{\mathrm{it}}$

$\mathrm{TACC}_{\mathrm{it}} / \mathrm{TA}_{\mathrm{i}, \mathrm{t}-1}=\alpha_{1}\left(1 / \mathrm{TA}_{\mathrm{i}, \mathrm{t}-1}\right)+\alpha_{2}\left(\left(\Delta \mathrm{REV}_{\mathrm{it}}-\Delta\right.\right.$ $\left.\left.\left.\mathrm{REC}_{\mathrm{it}}\right) / \mathrm{TA}_{\mathrm{i}, \mathrm{t}-1}\right)\right)+\alpha_{3}\left(\mathrm{PPE}_{\mathrm{i} t} / \mathrm{TA}_{\mathrm{i}, \mathrm{t}-1}\right)$

\section{Langkah II}

Dari persamaan regresi diatas, NDACC (non discretionary) dapat dihitung dengan memasukkan kembali koefisien -koefisien alpha (o) yaitu sebagai berikut:

$\mathrm{NDACC}_{\mathrm{it}}=\alpha_{1}\left(1 / \mathrm{TA}_{\mathrm{i}, \mathrm{t}-1}\right)+\alpha_{2}\left(\left(\Delta \mathrm{REV}_{\mathrm{i} \mathrm{t}}-\Delta \mathrm{REC}_{\mathrm{it}}\right) / \mathrm{TA}_{\mathrm{i}, \mathrm{t}-}\right.$ $\left.{ }_{1}\right)+\alpha_{3}\left(\mathrm{PPE}_{\mathrm{it}} / \mathrm{TA}_{\mathrm{i}, \mathrm{t}-1}\right)$

Keterangan :

TACC $_{\mathrm{it}} \quad$ : Total accruals perusahaan $\mathrm{i}$ pada periode $\mathrm{t}$

EXBT $_{\text {it }} \quad$ Earnings Before Extraordinary Item perusahaan i pada periode $\mathrm{t}$

$\mathrm{OCF}_{\text {it }} \quad$ : Operating Cash Flows perusahaan i pada periode $\mathrm{t}$

$\mathrm{NDACC}_{\text {it }}$ : Non discretionary accruals perusahaan i pada periode $\mathrm{t}$

$\mathrm{TA}_{\mathrm{i}, \mathrm{t}-1} \quad$ : Total aktiva perusahaan $\mathrm{i}$ pada periode $\mathrm{t}$

$\begin{array}{ll}\mathrm{REV}_{\text {it }} & \text { : Revenue perusahaan i pada periode } \\ \mathrm{t} & \text { : Receivable perusahaan } \mathrm{i} \text { pada } \\ \mathrm{REC}_{\mathrm{it}} & \\ \text { periode } \mathrm{t} & : \text { Nilai aktiva tetap (gross) } \\ \mathrm{PPE}_{\mathrm{it}} & \end{array}$

\section{Langkah III}

Selanjutnya dapat dihitung nilai discretionary accruals sebagai berikut:

$\mathbf{D A C C}_{i \mathbf{t}}=\left(\mathbf{T A C C}_{\mathbf{i t}} / \mathbf{T A}_{\mathrm{i}, \mathrm{t}-1}\right)-\mathbf{N D A C C}_{\mathbf{i t}}$

DACC $_{\text {it }}$ : Discretionary accruals perusahaan i pada periode $\mathrm{t}$

TACC $_{\text {it }}$ : Total accruals perusahaan i pada peride $\mathrm{t}$

$\mathrm{TA}_{\mathrm{i}, \mathrm{t}-1} \quad$ : Total aktiva perusahaan i pada periode $\mathrm{t}$

NDACC $_{i t}$ : Non discretionary accruals perusahaan $\mathrm{i}$ pada periode $\mathrm{t}$

Langkah analisis yang telah diungkap, dapat terlihat dari DACC yang telah dihitung, maka dilakukan untuk melihat tindakan manajemen laba.

\section{b. Kepemilikan Institusional}

Kepemilikan institusional merupakan kepemilikan saham perusahaan oleh investor besar seperti perusahaan asuransi, bank, dana pensiun, dan insvestment banking yang membeli saham perusahaan dalam jumlah besar (Agustia, 2013). Kepemilikan institusional diukur dengan jumlah saham yang dimiliki oleh insvestor institusional dibandingkan dengan total saham perusahaan.

$\begin{array}{cc}\text { Kepemilikan } & \text { Institusional } \\ \frac{\text { JUMLAH SAHAM INSTITUSIONAL }}{\text { TOTAL SAHAM PERUSAHAAN }} & \end{array}$

\section{c. Kepemilikan Manajerial}

Kepemilikan manajerial adalah saham yang dimiliki oleh manajemen secara pribadi maupun saham yang dimiliki oleh anak cabang perusahaan bersangkutan beserta afiliasinya. Indikator untuk mengukur kepemilikan manajerial adalah menggunakan dummy, yaitu ketika perusahaan mempunyai kepemilikan manajerial dinilai angka 1 jika tidak ada dinilai angka 0 .

\section{d. Proporsi Dewan Komisaris Independen}

Peran dewan komisaris adalah memonitor kebijakan direksi yang diharapkan dapat meminimalisir permasalahan agensi yang muncul antara dewan direksi dan pemegang saham. Jumlah 
komisaris independen wajib mewakili sedikitnya $30 \%$ dari jumlah komisaris dalam dewan komisaris (peraturan BAPEPAM-LK No.IX.1.5). Proporsi dewan komisaris independen dihitung dengan menggunakan presentase dari komisaris independen dibandingkan dengan total komisaris.

Proporsi dewan komisaris independen $=$ JUMLAH KOMISARIS INDEPENDEN TOTAL KOMISARIS

\section{e. Ukuran Komite Audit}

Ukuran komite audit didefinisikan sebagai keberadaan komite audit yang dimiliki oleh suatu perusahaan. Variabel komite audit dalam penelitian ini diukur dengan menggunakan jumlah anggota komite audit yang ada di perusahaan. Berdasarkan peraturan BAPEPAM No IX.I.5 dijelaskan bahwa keberadaan komite audit sekurang-kurangnya terdiri dari 3 orang dimana komisaris independen perusahaan menjadi ketua komite, sedangkan yang lain adalah pihak ekstern yang independen dan minimal salah seorang diantaranya memiliki kemampuan di bidang akuntansi dan keuangan.

\section{f. Leverage}

Variabel leverage menggunakan rasio Debt to Asset, yaitu perbandingan total kewajiban (hutang jangka pendek dan hutang jangka panjang) dengan total aset yang dimiliki perusahaan pada akhir tahun (Agustia, 2013).

$$
\text { Leverage }=\frac{\text { TOTAL HUTANG }}{\text { TOTAL ASET }}
$$

\section{g. Free Cash Flow}

Free cash flow merupakan arus kas aktual yang didistribusikan kepada investor sesudah perusahaan melakukan semua investasi dan modal kerja yang diperlukan untuk menjaga kelangsungan operasionalnya.

$\mathrm{FCF}=\frac{C F O-C F I}{\text { TOTAL ASET }}$

Keterangan :

FCF : Free cash flow

CFO : Cash flow Operasi

CFI : Cash flow Investasi

\section{Metode Analisis Data}

Pengujian hipotesis dilakukan dengan menggunakan metode analisis regresi berganda Sebelum dilakukan uji hipotesis maka dilakukan uji asumsi klasik, yaitu uji normalitas, uji multikolinieritas, uji heterokedastisitas dan uji autokorelasi. Model persamaan regresi sebagai berikut. $\mathrm{DACCt}=\alpha+\beta_{1} \mathrm{KI}+\beta_{2} \mathrm{KM}+\beta_{3} \mathrm{PDK}+\beta_{4} \mathrm{KA}+$ $\beta_{5} \mathrm{LEV}+\beta_{6} \mathrm{FCF}+\varepsilon$

Keterangan:

DACCt = Nilai absolut akrual diskresioner pada tahun $\mathrm{t}$

$\alpha \quad=$ Konstanta

$\beta_{1}-\beta_{6} \quad=$ Koefisien regresi

KIt $=$ Kepemilikan institusional pada

tahun $\mathrm{t}$

KMt =Kepemilikan manajerial pada

tahun $\mathrm{t}$

PDKt =Proporsi dewan komisaris independen pada tahun $\mathrm{t}$

$\begin{array}{ll}\text { Kat } & =\text { Komite Audit pada tahun } \mathrm{t} \\ \mathrm{LEVt} & =\text { Leverage ratio pada tahun } \mathrm{t} \\ \mathrm{FCFt} & =\text { Free Cash Flow } \\ \varepsilon & =\text { Error }\end{array}$

\section{Hasil Penelitian}

Hasil analisis regresi linear berganda dengan menggunakan program SPSS dapat ditunjukkan pada tabel 2 berikut ini :

Tabel 2

Hasil Uji Hipotesis

\begin{tabular}{|c|c|c|c|c|c|c|}
\hline Variabel & $\begin{array}{c}\text { Koefisien } \\
\text { LQ45 }\end{array}$ & sign & $\begin{array}{c}\text { Koefisien } \\
\text { JII }\end{array}$ & sign & ket & ket \\
\hline Konstanta & ,064 & , 146 &, 053 &, 737 & & \\
\hline $\begin{array}{l}\text { Kepemilikan } \\
\text { Institusional }\end{array}$ & ,025 & ,512 &,- 015 &, 470 & TS & TS \\
\hline $\begin{array}{l}\text { Kepemilikan } \\
\text { Manajerial }\end{array}$ & ,009 & ,463 &,- 021 &, 271 & TS & TS \\
\hline $\begin{array}{l}\text { Proporsi } \\
\text { Dewan } \\
\text { Komisaris }\end{array}$ & ,072 & , 146 & ,049 &, 126 & $\mathrm{TS}$ & TS \\
\hline $\begin{array}{l}\text { Komite } \\
\text { Audit }\end{array}$ & ,002 & ,767 & ,076 &, 174 & $\mathrm{TS}$ & TS \\
\hline Leverage &,- 069 &, 035 &,- 276 & ,012 & $\mathrm{S}$ & $\mathrm{S}$ \\
\hline $\begin{array}{l}\text { Free Cash } \\
\text { Flow }\end{array}$ &,- 324 & ,000 &,- 043 & ,016 & S & S \\
\hline Adj. $R^{2}$ &, 285 & ,102 & & & & \\
\hline $\mathrm{F}$ & 10,492 & 2,616 & & & & \\
\hline Sig. & ,000 & ,028 & & & & \\
\hline
\end{tabular}

Sumber: Hasil olah data, 2018 
Uji Asumsi Klasik

\section{Uji Normalitas}

Pengujian normalitas data dilakukan dengan menggunakan One Sample Kormogorov-Sminov Test, dengan melihat tingkat signifikansi 0,05 pada asymp.sig (2-tailed). Hasil pengujian dapat dilihat pada tabel 2 bahwa seluruh data yang diteliti berdistribusi normal. Lihat tabel 3

Tabel 3

Uji Normalitas One Sample Kormogorov-Sminov Test

\begin{tabular}{lrc}
\hline \hline Keterangan & $\begin{array}{c}\text { Unstandardized } \\
\text { Residual } \\
\text { LQ 45 }\end{array}$ & $\begin{array}{c}\text { Unstandardized } \\
\text { Residual } \\
\text { JII }\end{array}$ \\
\hline $\begin{array}{l}\text { Kolmogorov- } \\
\text { Smirnov Z } \\
\begin{array}{l}\text { Asymp. Sig. } \\
\text { (2-tailed) }\end{array}\end{array} \quad 0,714$ & 0,541 \\
Hasil & 0,688 & 0,931 \\
& $\begin{array}{r}\text { data } \\
\text { berdistribusi nor } \\
\text { mal }\end{array}$ & $\begin{array}{c}\text { data } \\
\text { berdistribusi } \\
\text { normal }\end{array}$ \\
\hline \hline
\end{tabular}

Sumber: Hasil olah data, 2016

\section{Uji Multikolinieritas}

Uji multikolinieritas pada penelitian ini bertujuan untuk menguji apakah model regresi ditemukan adanya korelasi yang tinggi diantara variabel independen dengan melihat besarnya nilai Tolerance Value dan Variance Inflation Factor (VIF). Pada penelitian ini menggunakan nilai tolerance dan nilai tolerance value lebih dari 0,1 atau $10 \%$. Maka, dapat dibuktikan bahwa pada model regresi lolos uji multikolinearitas.

Tabel 4

Uji Multikolinieritas

\begin{tabular}{|c|c|c|c|}
\hline Variabel & $\begin{array}{c}\text { Tolerance } \\
\text { LQ45 }\end{array}$ & $\begin{array}{c}\text { Tolerance } \\
\text { JII }\end{array}$ & keterangan \\
\hline Kepemilikan & ,819 &, 821 & Bebas \\
\hline Institusional & & & Multikolinieritas \\
\hline Kepemilikan & ,926 & ,682 & Bebas \\
\hline Manajerial & & & Multikolinieritas \\
\hline Proporsi & ,863 & ,872 & \\
\hline Dewan & & & Bebas \\
\hline Komisaris & & & Multikolinieritas \\
\hline Komite & ,929 &, 808 & Bebas \\
\hline Audit & & & Multikolinieritas \\
\hline Leverage & ,913 & ,788 & Bebas \\
\hline & & & Multikolinieritas \\
\hline Free Cash & ,719 &, 813 & Bebas \\
\hline
\end{tabular}

\begin{tabular}{ll}
\hline \hline Flow & Multikolinieritas \\
\hline \hline
\end{tabular}

Sumber: Hasil olah data, 2018

\section{Uji Heterokedastisitas}

Pengujian heterokedastisitas di uji pada penelitian ini menggunakan uji glejser. Semua variabel independen menunjukkan nilai probabilitas lebih dari 0,05. Maka, dari uji glejser yang dilakukan dapat dibuktikan bahwa pada model regresi lolos uji heterokedastisitas.

Tabel 5

Uji Heterokedastisitas-Uji Glejser

\begin{tabular}{lccl}
\hline \hline Variabel & Sig & Sig & Keterangan \\
\hline $\begin{array}{l}\text { Kepemilikan } \\
\text { Institusional }\end{array}$ &, 470 &, 800 & Bebas \\
Kepemilikan &, 271 &, 794 & $\begin{array}{l}\text { Heterokedastisitas } \\
\text { Bebas } \\
\text { Manajerial }\end{array}$ \\
$\begin{array}{l}\text { Proporsi Dewan } \\
\text { Komisaris }\end{array}$ &, 116 &, 460 & $\begin{array}{l}\text { Heterokedastisitas } \\
\text { Bebas }\end{array}$ \\
Komite Audit &, 174 &, 757 & $\begin{array}{l}\text { Heterokedastisitas } \\
\text { Bebas }\end{array}$ \\
&, 121 &, 261 & $\begin{array}{l}\text { Heterokedastisitas } \\
\text { Bebas } \\
\text { Leverage }\end{array}$ \\
&, 143 &, 365 & $\begin{array}{l}\text { Heterokedastisitas } \\
\text { Bebas }\end{array}$ \\
Free Cash Flow & & & Heterokedastisitas \\
\hline
\end{tabular}

Sumber: Hasil olah data, 2018

\section{PEMBAHASAN}

1. Hipotesis 1 (Kepemilikan Institusional Berpengaruh terhadap Manajemen Laba akrual)

Kepemilikan institusional tidak berpengaruh terhadap manajemen laba akrual baik pada perusahaan yang tergabung di LQ 45 dan JII. . Hasil perhitungan analisis diketahui tingkat signifikansi sebesar 0,512 dan 0,470 memiliki nilai lebih tinggi dari $\alpha=0,05$. Sehingga dapat disimpulkan $\mathrm{H}_{1}$ ditolak, artinya kepemilikan istitusional tidak berpengaruh terhadap manajemen laba akrual. Pada penelitian ini menunjukkan hasil bahwa kepemilikan institusional tidak memiliki kemampuan untuk mengendalikan pihak manajemen sehingga tidak dapat mengurangi manajemen laba. Investor institusional yang memiliki kepemilikan saham yang besar seharusnya mempunyai kekuatan yang lebih dalam mengontrol kegiatan 
operasional kegiatan. Kenyataan yang terjadi adalah manajemen laba tidak bisa dikendalikan oleh kepemilikan institusional. Hal ini dikarenakan investor institusional tidak berperan sebagai sophisisticated investor yang memiliki banyak kemampuan dan kesempatan untuk memonitor dan mendisiplinkan manajer agar lebih terfokus pada nilai perusahaan, serta membatasi kebijakan manjemen dalam melakukan manipulasi laba, melainkan berperan sebagai pemilik sementara yang terfokus pada current management performance (Yang et al, 2009). Hasil penelitian ini mendukung penelitian Guna dan Herawati (2010), Kusumaningtyas (2012) dan Agustia (2013) yang membuktikan bahwa kepemilikan institusional tidak berpengaruh terhadap manajemen laba.

\section{Hipotesis 2 (Kepemilikan Manajerial Berpengaruh terhadap Manajemen Laba Akrual)}

Kepemilkan manajerial tidak berpengaruh terhadap manajemen laba akrual. Hasil perhitungan menunjukkan bahwa nilai signifikansi sebesar 0,463 dan 0.271 memiliki nilai lebih tinggi dari $\alpha=0,05$. Sehingga $\mathrm{H}_{2}$ ditolak, yang berarti kepemilikan manajerial tidak berpengaruh terhadap manajemen laba. Hasil penelitian ini menjelaskan bahwa peningkatan jumlah kepemilikan manajerial tidak mampu mengurangi konflik agensi yang timbul akibat dari hubungan keagenan. Jumlah kepemilikan manajerial yang besar tidak mampu mensejajarkan kepentingan manajemen dan pemegang saham, sehingga tujuan perusahaan dalam mencapai nilai perusahaan yang tinggi tidak tercapai. Kepemilikan saham yang dimiliki oleh manajer tidak mampu mempengaruhi pengambilan keputusan dalam menentukan kebijakan penjualan, biaya, dan produksi yang diterapkan perusahaan sehingga adanya kepemilikan saham oleh manajemen tidak mampu mengurangi manajemen laba (Kusumawati et al, 2013). Presentase manajer yang memiliki saham relatif kecil jika dibandingkan dengan keseluruhan modal yang dimiliki investor umum, maka menyebabkan terjadinya kegagalan pihak manjemen yang juga merupakan pemilik modal perusahaan dalam meningkatkan kualitas dan proses pelaporan keuangan. Hasil penelitian ini mendukung penelitian Kusumawati et al (2013), Wida dan Suartana (2014) dan Agustia (2013) yang membuktikan bahwa kepemilikan manajerial tidak berpengaruh terhadap manajemen laba akrual.

\section{Hipotesis 3 (Proporsi Dewan Komisaris Independen Berpengaruh terhadap Manajemen Laba Akrual)}

Proporsi dewan komisaris independen tidak berpengaruh terhadap manajemen laba akrual. Hasil ini dibuktikan dari perhitungan regresi yang diperoleh tingkat signifikansi sebesar 0,146 dan 0.126 memiliki nilai lebih tinggi dari $\alpha=0,05$. Sehingga $\mathrm{H}_{3}$ ditolak, yang berarti proporsi dewan komisaris independen tidak berpengaruh terhadap manajemen laba. Dapat dirtikan juga bahwa semakin banyak komisaris independen dalam perusahaan belum berhasil mengurangi praktik manajemen laba. Hal ini menunjukkan komisaris independen belum efektif dalam menjalankan tanggungjawabnya mengawasi kualitas pelaporan keuangan demi membatasi manajemen laba diperusahaan (Kusumawati, 2013). Sebagian besar penunjukkan atau pengangkatan dewan komisaris independen dilakukan dalam Rapat Umum Pemegang Saham (RUPS) dan dipilih oleh pemegang saham mayoritas, sehingga apabila tidak sejalan dengan keputusan pemilik maka perusahaan dapat melakukan pergantian. Jadi, meskipun presentase dewan komisaris independen relatif besar, tetapi mereka tidak benar-benar dapat bertindak secara independen dalam menjalankan fungsi pengawasan karena terbatas oleh peraturan dan kebijakan dari pemegang saham mayoritas, sehingga sulit untuk mewujudkan pelaksanaan good corporate governance secara optimal untuk membatasi praktik manajemen laba (Agustia, 2013). Hasil penelitian ini mendukung penelitian dari Agustia (2013) yang membuktikan bahwa proporsi dewan komisaris tidak berpengaruh terhadap manajemen laba.

\section{Hipotesis 4 (Komite Audit Berpengaruh terhadap Manajemen Laba Akrual)}

Komite audit tidak berpengaruh terhadap manajemen laba akrual. Hasil perhitungan membuktikan tingkat signifikansi sebesar 0,767 dan 0.174 memiliki nilai signifikansi lebih tinggi dari $\alpha=$ 0,05. Sehingga $\mathrm{H}_{4}$ ditolak, yang berarti komite audit tidak berpengaruh terhadap manjemen laba. Komite audit suatu perusahaan sebagai salah satu mekanisme corporate governance belum mampu mengurangi praktik manajemen laba. Jumlah komite audit yang 
besar belum mampu mempererat sistem pengendalian dan pengawasan komite audit pada manajemen. Kesulitan dalam melakukan koordinasi dan masalah komunikasi yang kurang efektif menjadi penyebabnya jika jumlah komite auudit terlalu besar. Sehingga peran komite audit kurang optimal dalam menjalankan fungsi pengawasan dan pengendalian pada manajemen perusahaan. Akibatnya akan muncul kesempatan untuk melakukan praktik manajemen laba (Zeptian dan Rohman, 2013). Hasil penelitian ini mendukung penelitian dari Yoghi dan Damayanthi (2016), Agustia (2013) dan Zeptian dan Rohman (2013) yang membuktikan bahwa komite audit tidak berpengaruh terhadap manajemen laba.

\section{Hipotesis 5 (Leverage Berpengaruh terhadap Manajemen Laba Akrual)}

Leverage berpengaruh terhadap manajemen laba akrual. Hasil dari regresi menunjukkan tingkat signifikansi sebesar 0,035 dan 0.012 . Nilai signifikansi memiliki nilai lebih rendah dari $\alpha=0,05$. Sehingga $\mathrm{H}_{5}$ diterima, yang artinya leverage berpengaruh terhadap manajemen laba, Perusahaan yang mempunyai rasio leverage yang tinggi, berarti proporsi aktivanya lebih rendah dibandingkan dengan proporsi hutangnya akan cenderung melakukan manipulasi dalam bentuk manajemen laba, diduga perusahaan belum bisa membayar hutang pada waktunya karena tidak dapat memenuhi kewajiban. Sehingga perusahaan yang leveragenya tinggi cenderung mengatur laba yang dilaporkan dengan menaikkan atau menurunkan laba periode masa datang ke periode saat ini. Leverage yang tinggi mengindikasikan hutang yang dimiliki cukup besar hal ini mengakibatkan risiko dan tekanan yang besar dari pihak kreditur maupun sebaliknya. Sebagian besar sampel yang digunakan dalam penelitian ini memiliki tingkat leverage yang rendah. Sehingga akan mengurangi tekanan dari pihak kreditur kepada pihak manajemen untuk melakukan tindakan manajemen laba. Hasil penelitian ini mendukung penelitian dari Agustia (2013) dan Sari dan Astika (2015) yang membuktikan bahwa leverage berpengaruh signifikan terhadap manajemen laba.

\section{Hipotesis 6 (Free Cash Flow berpengaruh terhadap Manajemen Laba Akrual)}

Free cash flow berpengaruh terhadap manajemen laba akrual. Hasil regresi pada penelitian ini membuktikan bahwa tingkat signifikansi sebesar 0,000 dan 0.016 memiliki nilai lebih rendah dari $\alpha=0,05$.
Sehingga $\mathrm{H}_{6}$ diterima, yang berarti free cash flow berpengaruh terhadap manajemen laba. Semakin besar free cash flow yang tersedia oleh perusahaan, maka semakin sehat perusahaan tersebut, sebaliknya semakin kecil free cash flow yang dimiliki perusahaan, maka perusahaan dapat dikatagorikan semakin tidak sehat. Perusahaan yang memiliki free cash flow positif mengindikasikan bahwa perusahaan lebih mampu bertahan dalam situasi yang buruk karena memiliki kesempatan untuk melakukan investasi dan belanja modal dalam rangka mempertahankan operasi yang sedang berjalan. Selain itu, free cash flow positif juga memberikan sinyal bagi investor, karena investor menilai bahwa perusahaan memiliki kinerja yang baik dan memiliki kas yang lebih untuk pembagian deviden (Yogi dan Damayanthi, 2016). Dapat disimpulkan bahwa perusahaan akan mampu meningkatkan harga sahamnya, yang berdampak praktek manajemen laba akrual akan terkurangi karena focus manajemen adalah melakukan ekspansi bisnis dan deversifikasi produk yang didukung oleh nilai free cashflow yang tinggi. Hasil penelitian ini mendukung dari penelitian Agustia (2013) dan Yoghi dan Damayanthi (2016) yang membuktikan bahwa free cash flow berpengaruh terhadap manajemen laba.

\section{SIMPULAN}

\section{Simpulan}

Berdasarkan hasil analisis dan pembahasan yang telah dilakukan dapat ditarik kesimpulan bahwa mekanisme corporate governance yang terdiri dari kepemilikan institusional, Kepemilkan manajerial, Proporsi dewan komisaris independen dan Komite audit tidak berpengaruh terhadap manajemen laba akrual pada perusahaan go public di Indonesia yang terdaftar di indeks JII maupun LQ45. Leverage berpengaruh terhadap manajemen laba akrual dan variable Free cash flow juga berpengaruh terhadap manajemen laba akrual pada perusahaan-perusahaan yang terdaftar pada undeks JII dan LQ45

\section{Implikasi Penelitian}

Agar dapat memberikan dampak positif bagi perusahaan dan pihak eksternal, maka peran dari dewan komisari dan komite audit perlu ditingkatkan. Fungsi lembaga tersebut untuk mengawasi/memonitor tindakan manajemen agar tidak cenderung pada perilaku oprtunistik. Selain itu perusahaan perlu meningkatkan kinerjanya dan dapat mengelola 
keuangan perusahaan dengan baik agar tidak terjadi leverage yang tinggi dan memiliki dana untuk keperluan investasi. Hal ini akan mendorong kenaikan nilai perusahaan .

\section{Keterbatasan}

Berdasarkan hasil analisis dan pembahasan, dapat dijelaskan berbagai keterbatasan dalam penelitian ini adalah (1) Data yang digunakan dalam penelitian ini terbatas pada tahun pengamatan selama tahun 20102015 karena pelaksanaan penelitian pada tahun 2016 sehingga data yang update adalah tahun 2015 . (2) Pendekatan yang digunakan dalam manajemen laba dalam penelitian ini menggunakan pendekatan akrual, Modified Jones sehingga belum komprehensif dalam mengukur manajemen laba. (3) Pengukuran variabel komite audit dan dewan komisaris dalam penelitian ini menggunakan kuantitas keanggotaan (dilihat dari jumlah komite audit dan proporsi dewan komisaris independen tergadap jumlah seluruh dewan komisaris).

\section{Saran}

Atas dasar kesimpulan dan keterbatan dalam penelitian ini, penulis memberikan rekomendasi sebagai berikut (1) Untuk penelitian yang bersumber dari data laporan keuangan sebaiknya menggunakan data yang paling baru sehingga hasilnya lebih berguna..(2) Pengukuran manajemen laba dapat dikombinasikan antara manajemen laba akrual dal riil. (3) Untuk pengukuran variabel komite audit dan proporsi dewan komisaris independen dapat digunakan proksi lain yang lebih spesifik, misal jumlah rapat komite audit dan kompetensi dewan komisaris independen. (4) Peneliti selanjutnya dapat menggunakan proksi corporate governance ekternal untuk dikombinasikan dalam menentukan variabel independen, misalnya kepemilikan keluarga, kepemilikan asing dan kepemilikan terkonsentrasi.

\section{Persantunan}

*) Hasil riset ini dibiayai dengan skim Penelitian dasar Unggulan Perguruan Tinggi tahun anggaran 2018 Nomor : 72.39/A.3-III/LPPM/III/2018.

Terimakasih kepada seluruh tim peneliti (dosen dan mahasiswa) yang telah berpartisipasi aktif dalam riset ini

\section{REFERENSI}

[1] Agustia, dian .2013. Pengaruh Faktor Good Corporate Governance, Free Cash Flow, dan Leverage Terhadap Manajemen Laba. Surabaya: Universitas Airlangga. Jurnal Akuntansi Dan Keuangan, vol. 15, no. 1,ISSN 1411-0288 print / ISSN 2338-8137 online

[2] Alves, Sandra Maria G. 2011. The Effect Of The Board Stuctureon Earning Management Evidance From Portugal. Journal Of Financial Reporting And Accounting, 9 (2), 141-160.

[3] Christiani, inggrid dan Nugrahantil, yeterina widi .2014. Pengaruh Kualitas Audit Terhadap Manajemen Laba. Salatiga: Universias kristen Satya Wacana. Jurnal Akuntansi dan Keuangan, Vol. 16, No. 1, ISSN 1411-0288 print / ISSN 2338-8137 online

[4] Dewanto. 2012. Pengaruh Corporate Governance Terhadap Manajemen Laba Dan Nilai Perusahaan. Tesis Tidak Diterbitkan. Surabaya Universitas Airlangga.

[5] Farida Dessy noor. 2012. Pengaruh Mekanisme Good Corporate Governance Dan Kompensasi Bonus Terhadap Manajemen Laba. Jurnal prestasi vol.9 No.1

[6] Ghozali, Imam. 2011. Aplikasi Analisis Multivariate dengan Program IBM SPSS 19. Edisi Kelima. Semarang: Badan Penerbit Universitas Diponegoro.

[7] Guna, Welvin dan Herawaty, Arleen. 2010.Pengaruh Mekanisme Good Corporate Governance, Independensi Auditor, Kualitas Audit Dan Faktor Lainnya Terhadap Manajemen Laba. Jurnal Bisanis Dan Akuntansi Vol 12 No 1.

[8] Handayani, Ratih Dan Indahningrum R P. 2009. Pengaruh Kepemilikan Manajerial, Kepemilikan Institusional, Deviden, Pertumbuhan Perusahaan, Free Cash Flow Dan Profitabilitas Terhadap Kebijakan Hutang Perusahaan. Jurnal Bisanis Dan Akuntansi Vol 11 No 3.

[9] Jensen, Michael C. Dan W.H. Meckling. 1976. "Theory of The Firm:manajerial Bahavior, 
Agensi Cost and Ownership Structure". Journal of Finacial Economics 3, p. 305-360.

[10] Kouki, M., Abderrazek, E., Hanen,A., And Slim, S. 2011. Does Corporate Governance Constrain Earning Manajemen? Evidence From U.S. Firms. European Journal Of Ekonomic, Financee And Administrative Sciences, 35, 58-71.

[11] Kusumaningtyas, metta .2012. Pengaruh Idependesi Komite Audit Dan Kepemilikan Institusional Terhadap Manajemen Laba. Jawa Tengah: STIE Bank BPD.Prestasi Vol.9, No.1. ISSN: $1411-1497$

[12] Kusumawati, Sari dan Trisnawati .2013. Pengaruh Asimetri Informasi Dan Mekanisme Corporate Governance Terhadap Praktik Earnings Management. Universitas Muhammadiyah Surakarta. Proceeding Seminar Nasional Dan Call For Papers Sancall, ISBN: 978-979-636-147-2

[13] Lin, J. W., J. F., And Yang, J. S. 2006. The Effect Of Audit Committe Performance On Earning Quality. Managerial Auditing Journal, 21 (9), 921-933.

[14] Pambudi, januar eky dan sumantri, farid addy .2014. Kualitas Audit, Ukuran Perusahaan Dan Leverage Terhadap Manajemen Laba. Tangerang:Universitas Muhammadiyah Tangerang. SNA 17

[15] Sari, Putri Puspita dan Astika, Ida Bagus Putra. Moderasi Good Corporate Governance Pada Pengaruh Antara Leverage Dan Manajemen Laba. E-jurnal Akuntansi Universitas Udayana 12.3. ISSN:2302-8556

[16] Siregar, Silvia V Dan Utama, Siddharma. 2005. Pengaruh Struktur Kepemilikan, Ukuran Perusahaan, Dan Praktik Corporate Covernance Terhadap Pengelolaan Laba (Earning Manajemen). SNA VIII Solo.

[17] Wahidawati Dan Naini, Dwi Ismiwatis. 2014. Pengaruh Free Cash Flow Dan Kepemilikan Institusional Terhadap Kebijakan Hutang Dan Nilai Perusahaan. Jurnal Ilmu Dan Riset Akuntansi Vol 3 No 4.
[18] Zeptian, Andra dan Rohman Abdul .2013. Analisis Pengaruh Penerapan Corporate Governance, Struktur Kepemilikan, Dan Ukuran Perusahaan Terhadap Manajemen Laba Pada Perbankan. Semarang: Universitas Diponegoro. Diponegoro Journal Of Accounting Vol.2, No. 4. sISSN: 2337-3806 